\title{
Evaluation of the Consumers' Trust Effect on Viral Marketing Acceptance Based on the Technology Acceptance Model
}

\author{
Seyed Fathollah Amiri Aghdaie ${ }^{1}$, Ali Sanayei ${ }^{2} \&$ Mehdi Etebari ${ }^{1}$ \\ ${ }^{1}$ Department of Management, University of Isfahan, Isfahan, Iran \\ ${ }^{2}$ ITM Research Group, University of Isfahan, Isfahan, Iran \\ Correspondence: Seyed Fathollah Amiri Aghdaie, Department of Management, University of Isfahan, Hezar \\ Jerib, St. Darvazeh Shiraz, Isfahan, Iran. Tel: 98-311-793-5251. E-mail: s.aghdaie@ase.ui.ac.ir
}

Received: July 1, 2012 Accepted: August 1, 2012 Online Published: November 2, 2012

doi:10.5539/ijms.v4n6p79 URL: http://dx.doi.org/10.5539/ijms.v4n6p79

\begin{abstract}
Integrating marketing principles with IT suggests new developed models for the marketing world such as viral marketing (VM). On the other hand, lots of prior studies have theoretically articulated and empirically examined the fact that trust is the essence of any human interaction especially for the online activities. Grounded on the viral marketing and trust literature, this descriptive and applied study, was targeted to integrate trust and viral marketing through the technology acceptance model (TAM). The purpose of this study is to evaluate the consumers' trust effect on viral marketing acceptance. Respondents to the questionnaire are 69 experts responsible for the selection and purchase of the medical equipment in Isfahan University of Medical Sciences, Iran. This study is originated from the perspective of the graduated consumers whose behaviors look different from the average. Applying a census-based methodology and statistical analysis, especially path analysis, the study showed that trust plays an important role in the attitude toward engaging in VM and in the intention of the consumers to engage and finally to actual use of VM by the experts. This study verified TAM too. It was followed by some managerial implications for the companies in order to design their viral marketing campaigns to be more successful. Finally, considering the findings and the limitations of this study, some academic suggestions for further researches have been made.
\end{abstract}

Keywords: viral marketing, word-of-mouth, trust, technology acceptance model

\section{Introduction}

The information technology has developed some new ideas and platforms for communications. As a powerful media, Internet has revolved the business on a world scale. One of the most important issues is that online communities interact free of geographical limitations (Reich, 2010). It has raised some challenges in understanding this new environment and consumers' action within it (Ulmanen, 2011). Today, "Internet users, spend a lot of time on the Internet to interact with others in order to communicate, collaborate, or cooperate through various channels and applications such as e-mail, online games, or instant messaging" (Fetscherin \& Lattemann, 2008).

According to the "small world" concept, "any pair of entities in a seemingly vast, random network can actually connect in a predictable way through relatively short paths of mutual acquaintance." Furthermore, each person is estimated to be directly connected to 300 acquaintances, thus using a simple exponential model, 90000 people are only two steps away from any given person and surprisingly, 27 million people are three steps away and etc. (Gray, Seigneur, Y. Chen \& Jensen, 2003)

Considering the small world concept, the demand for information, the good intention to share the experience or ideas about the products and services, the capability of the customer-to-customer $(\mathrm{C} 2 \mathrm{C})$ communications as the electronic peer-to-peer referrals on Internet and the potential for getting recommendations from mutual acquaintances have raised a considerable potential for Viral Marketing (VM) (Ridings, Gefe \& Arinze, 2002; Bruyn and Lilien, 2008) which is the effective mixture of the traditional idea called Word of Mouth (WOM) and the modern tools provided within the virtual environment (Chaffey, Ellis-Chadwick, Mayer, \& Johnston, 2006). This is why Kurucz (2008) believes that VM is going to be the most important issue of promotion and Chaffey et al. (2006) emphasize that it is increasingly being used for commercial purposes. Sormunen (2009) argues that 
coming into the 2000s, viral marketing became a new media phenomenon, attracting increasing interest in the marketing literature.

VM can be deployed based on different instruments and forms. Each form of VM offers different perspectives for researchers to investigate. On the other hand, to design a viral marketing campaign, it is advisable to know both target consumers and their associates very well (Sormunen, 2009; Yang, Liu \& Zhou, 2012). The focus of this study shifts to just one form of VM which is email. In the studied society, the global social networks are limited to be used and the users prefer to work with email which is why this channel has been selected for this study.

Lots of prior studies have theoretically articulated and empirically examined the fact that trust is the essence of any human interaction especially within the uncertain virtual environment. It is believed that trust is an important factor for the acceptance of the Internet-based technologies and engaging in on-line interactions (Hoffman, Novak \& Peralta, 1999; Gefen, 2000; Salo \& Karjaluoto, 2007). On the other hand, Hasic and Sobtsenko (2009) argue that trust is an important factor in trying to explain the power of WOM and it is discussed that "trust in information is developing into a vitally important topic as the Internet becomes increasingly ubiquitous within society" (Kelton, Fleischmann \& Wallace, 2008). As a result, it looks that trust is a challenging factor in VM too. This study calls for this challenge with the aim of finding the relationship between trust and consumers' acceptance of viral marketing as an aspect of information technology through the Technology Acceptance model (TAM) which is originally introduced by F. D. Davis (1986) (F. D. Davis, Bagozzi, \& Warshaw, 1989). Adopting this approach, trust as an external variable has been integrated with the original variables of the model as perceived usefulness, perceived ease of use, attitude toward use, intention and actual use.

To meet this objective, first, we begin with a deep review of the literature on viral marketing, trust and TAM. Next, an outline of the methodological approach and the reported results of the study are followed. Finally, the conclusion, limitations, managerial implications and academic suggestions are discussed.

\section{Viral Marketing}

\subsection{Viral Marketing History}

In 1997, Steve Jurvetson used the term "viral marketing" as "network-enhanced word of mouth" and as an effective way in reaching a large number of people rapidly in the same way as a natural virus or a computer virus, describing the marketing strategy of the free email service of Hotmail which is believed to be one of the most successful samples of viral marketing (Woerndl, 2008; Palka, Pousttchi \& Wiedemann, 2009; Sormunen, 2009; Xavier \& Summer, 2009; Eckler \& Rodgers, 2010). In recent years, many famous and great companies such as Nike, McDonalds (Testa, 2007), Microsoft, Philips, Sony, Ford, BMW (Lans, Bruggen, Eliashberg \& Wierenga, 2009), Procter and Gamble, Toyota, and Burger King (Xavier \& Summer, 2009), have used viral contents, however, it is found that Fortune 500 companies were far less likely to engage in viral campaigns than non-Fortune 500 companies (Porter \& Golan, 2006).

Kulp (2007) discusses the shortage of empirical studies on VM. In addition, limited research has been done on different aspects of viral marketing such as consumer acceptance, so it's still in its infancy and it calls for more academic researches (Kurucz, 2008; Xavier \& Summer, 2009; Sormunen, 2009). Furthermore, Wiedemann, Palka and Pousttchi (2008) and Palka et al. (2009) argue that although there is some evidence on the usefulness of viral marketing from marketers' perspective, little is known about the motivations, attitudes, and behaviors of consumers engaged in this marketing instrument. Their focus was on Mobile VM.

\subsection{Viral Marketing Definition}

Being a relatively new concept, there are several different interpretations of VM (Kurucz, 2008). Kiss and Bichler (2008) define viral marketing as "marketing techniques that use social networks to produce increases in brand awareness through self-replicating viral diffusion of messages, analogous to the spread of pathological and computer viruses". From the point of view of Kim and Lowrey (2010), viral marketing refers to "a marketing strategy or a marketing phenomenon that facilitates and encourages people to pass along a marketing message to other people".

VM can be considered to be the equivalent of "Online word-of-mouth" which refers to "all informal communications related to the usage or characteristics of particular goods and service or their sellers directed at consumers through Internet-based technology" (Litvin, Goldsmith \& Pan, 2008). Sometimes it's referred to as "electronic word-of-mouth (eWOM)" or more interesting "word-of-mouse" (Litvin et al., 2008; Ulmanen, 2011). Xavier and Summer (2009) refer to VM as an electronic extension of word-of-mouth. 
Though the focus of this term is mainly on online interactions, Kurucz (2008) suggests that other traditional marketing techniques basing on the word-of-mouth effect should not been excluded because of its offline context. Some researchers have emphasized the nature of informal environment of VM (Porter \& Golan, 2006; Litvin et al., 2008; Woerndl, 2008). Eckler and Rodgers (2010) discuss the advantages of VM as the reduced cost of promotion, increased credibility, increased visibility, decreased interruption, and improved format flexibility. They discuss disadvantages as the reduced control of the marketer, increased reliance on consumers' motivation, and increased risk of negative reactions.

\subsection{Viral Marketing Instruments}

A wide range of instruments can be used for the purpose of VM. Based on the wider definition of VM, including online and offline context, Kurucz (2008) identified 15 different VM instruments as "customer recommendations" e.g. clicking buttons such as "Tell-A-Friend", "E-cards" e.g. elfyourself.com, "Search engines" e.g. AdWords on Google, "links" e.g. registering firm in link-lists, "Communities" e.g. Nike's Jogabonito, "Networks" e.g. Facebook.com, "Chat rooms", "Blogs", "Wikis", "Widgest", "Online games or Advergames", "News letters", "Microsite", "Free services" and finally "Affiliate programs".

The other researches usually discussed email, social networks, chat rooms, discussion forums and services like YouTube as the most important channels for spreading viral messages (e.g. Woerndl, 2008; Xavier \& Summer, 2009). Some researchers such as Phelps, Lewis, Mobilio, Perry \& Raman (2004), Dobele, Toleman, and Beverland (2005), Bruyn and Lilien (2008), Chiu, M. Lee, and J. R. Chen (2008) and Lans et al. (2009) conducted their studies mainly based on email.

Some researchers believe that VM campaigns are not limited to the Internet-based instruments. It includes every media through which the message can be spread in a virus way. In fact their focus shifts from the instrument of diffusion to the kind of diffusion. In their view, mobile viral marketing can be considered as an important kind of viral marketing too. The work of Pousttchi and Wiedemann (2007), Wiedemann et al. (2008), Palka et al. (2009), Yang and Zhou (2011), and Yang et al. (2012) are some examples of mobile viral marketing studies.

\section{Word-of-mouth}

Since word-of-mouth is known as the mother of VM (Litvin et al., 2008; Xavier and Summer 2009; Ulmanen, 2011), a closer look at it is required. Word-of-mouth is referred to as "the information independent from companies or sponsor communicated between consumer and a friend, colleague or other acquaintance in a medium perceived to be independent of the company" (Ulmanen, 2011) or simply, "product information transmitted by individual consumers on an informal basis" (Kulp, 2007). Palka et al. (2009) suggest more accurate definition as "oral, person-to-person communication between a communicator and a recipient who perceives the respective message as non-commercial although the subject is a brand, product, or service."

The common concept highlighted in all of these definitions is the independence from the company or the non-commercial nature of the messages. Finally, the difference between eWOM and WOM is that eWOM is deployed through a written way and compared to what is presented through oral way, it usually looks to be more believable (Ulmanen, 2011).

\section{Trust}

\subsection{Trust Definition}

There is a plethora of material on trust, but spread across several thousand sources from psychology to sociology and information systems to marketing (Arnott, 2007; Walter, Battiston \& Schweitzer, 2007; Ulmanen, 2011), thus it's not surprising that "trust", like any other concept in this level in the literature, has variety of definitions which is "basically a consequence of the construct's complexity" (Ingenhoff \& Sommer, 2010). Though there are a confusing variety of definitions for this very broad concept, as Mayer, J. H. Davis, \& F. D. Davis (1995) discuss, it's not easy to be defined or more accurately as Zhang et al. (2012) argue "there is no commonly agreed definition that fits all purposes".

Mui, Mohtashemi, and Halberstadt (2002) defined trust as a "subjective expectation an agent has about another's future behavior based on the history of their encounters". From the other perspective, trust refers to "the measure of willingness to believe in a user based on its competence (e.g. goodness, strength, ability) and behavior within a specific context at a given time" (Yuan, 2010). It also can be seen simply as "the opposite of opportunistic action" (Ingenhoff \& Sommer, 2010). Trust has been discussed as a context-specific, multi-faceted and dynamic concept. (Wang \& Vassileva, 2007) 
Wang and Vassileva (2003) define trust as "a peer's belief in another peer's capabilities, honesty and reliability based on its own direct experiences." It can be compared to "reputation" which refers to "a peer's belief in another peer's capabilities, honesty and reliability based on recommendations received from other peers."

\subsection{Online Trust}

As for the online trust, also there are many definitions. Online trust is "when a consumer has confidence in an e-merchant's reliability and integrity to perform online transactions successfully" (Peštek, Resić, \& Nožica, 2011). Regarding the interpretation of trust in virtual communities, Zhang et al. (2012) refer to trust as "openness to discussion and willingness to share data".

Online trust is not limited to the persons as trustee. The characteristics of the merchant, characteristics of the web site and the underlying technology infrastructure as the factors that affect online trust have been discussed (Yazdanifard, Hoe, Islam, and Emami, 2011). On the other hand, trust in information and trust in the information systems through which the information is handled are studied by some researchers like Pickard, Gannon-Leary, and Coventry (2010) and Ulmanen (2011). Kelton et al. (2008) support the view that online trust is not limited to issues like security, technical reliability, or e-commerce but it includes the problem of trust in the information obtained from the Internet. They present a model for trust in digital information by integrating the research on trust from the behavioral and social sciences with the research on information quality and human-computer interaction.

\subsection{Trust Dimensions}

Literature on trust implies that there is no commonly agreed dimension for assessing trust. Regarding trust in the company and CEO, Ingenhoff and Sommer (2010) applied ability (expertise), integrity ("the perception of the trustee as having a strong sense of justice and acting according to it."), benevolence ("the trustees' attempts to do good to the trustors without thinking of their own benefit."), and information quality (comprehensiveness) (Ingenhoff \& Sommer, 2010). Focusing on organizational trust, the researchers suggest that integrity, commitment and dependability represent the trust construct very well (Chathoth, Mak, Sim, Jauhari, \& Manaktola, 2011) but Wang and Vassileva (2003) put the stress on capabilities, honesty and reliability.

Regarding e-commerce, S. C. Chen and Dhillon (2003) have applied competence, ability and integrity. Ridings et al. (2002), for studying trust in virtual communities, applied two dimensions as ability and benevolence/integrity. They believe that there is close relationship between benevolence and integrity, so they have combined them as one dimension and showed that trust has a downstream effect on members' intentions to both give information and get information through the virtual community.

Use relevance, timeliness, accuracy and comprehensiveness have been considered as the dimensions of information quality which means the trustworthiness or credibility of information (Cheung, M. Lee, \& Rabjohn, 2008). From reviewing trust literature, three more frequent dimensions of trust which have been identified by Ulmanen (2011) are ability, integrity and benevolence, however Ulmanen (2011) considered friendliness of a community and information value as two dimensions of trust in online word-of-mouth and he showed the effect of these dimensions. Surprisingly, he has left trustworthiness of the website or other information systems, because he believes that it was examined through perceived systems quality or perceived usability.

From the reviewed literature, it can be concluded that the dimensions for assessing trust, depends on the context, studied population and the ideas of the researchers.

\section{Technology Acceptance Model}

The most applied models developed for the researches of the information technology acceptance are Innovation Diffusion Theory (IDT) (Rogers, 1962, 1995), Theory of Reasoned Action (TRA) (Fishbein \& Ajzen, 1975), Theory of Planned Behavior (TPB) (Ajzen, 1991), Technology Acceptance Model (TAM) (F.D. Davis, 1989 and F.D. Davis et al., 1989), and Unified Theory of Acceptance and Use of Technology (UTAUT) (Venkatesh, Morris, G. B Davis, \& F. D. Davis, 2003) (Cited by Koivisto, 2009).

Adopting the well-established causal chain of beliefs, attitude, intention and behavior, TAM as a parsimonious model (Heijden, 2003) with the characteristics like simplicity, potential and understandability (King \& He, 2006), has probably been the most widely cited approach (Hubona \& Burton, 2003; Y. Lee, Kozar \& Larsen, 2003). TAM has been theoretically and empirically justified (Straub, Keil \& Brenner, 1997; Venkatesh \& F. D. Davis, 2000; Roberts \& Henderson, 2000).

According to this model, "perceived usefulness" which is defined as "the degree to which a person believes that using a particular system would enhance his or her job performance", and "perceived ease of use" which, in 
contrast, refers to "the degree to which a person believes that using a particular system would be free of effort" are two critical factors of adoption of a new technology by users.

This model integrates perceived usefulness, perceived ease of use, attitude toward the action, intention and actual use as the original variables of the model with the external variables. It provides an informative representation of the mechanisms by which design choices influence user acceptance, and should therefore be helpful in applied contexts for forecasting and evaluating user acceptance of information technology (F. D. Davis et al., 1989). (Figure 1).

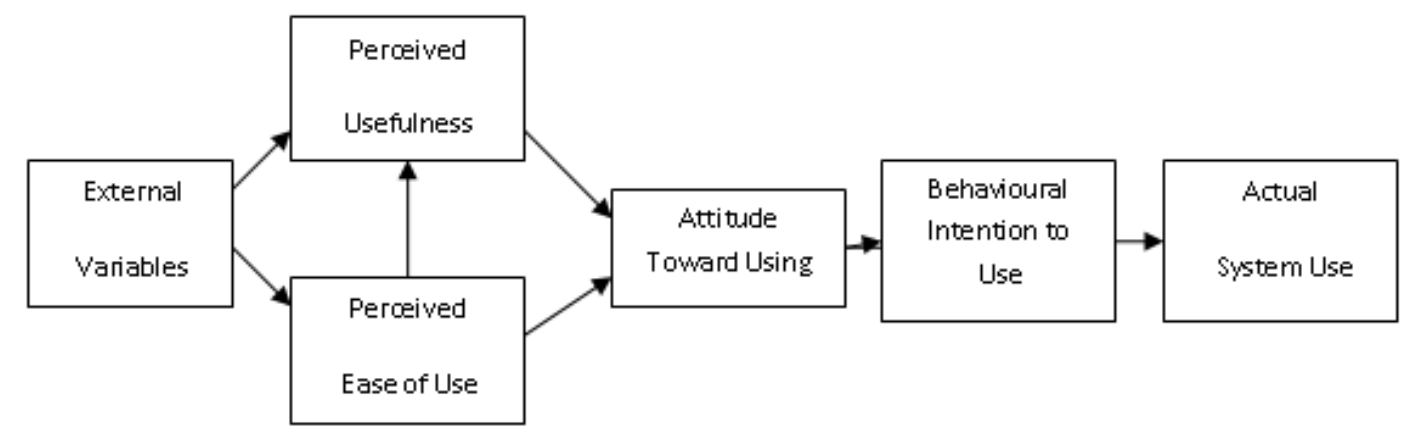

Figure 1. The technology acceptance model (F.D. Davis et al., 1989)

\section{Background of Research}

Some studies on the relationship between viral marketing and trust, integrating trust with TAM, integrating viral marketing with TAM, and Email viral marketing will be discussed as the background of the research. This discussion makes a scientific basis for the hypotheses.

\subsection{Viral Marketing and Trust}

Ulmanen (2011) in a study, "Antecedents of and their effect on trust in online word-of-mouth: case Finnish discussion forums" argues that trust in online word-of-mouth has a significant impact on future intention to use the discussion forum.

Palka et al. (2009) in a study, "Mobile word-of-mouth- A grounded theory of mobile viral marketing", found that risk and trust as the security-related conditions are effective factors in the stages of viral marketing especially in the stage of opening the messages. Their findings also suggest creating amusing and enjoyable viral content. The other researches confirm the role of entertainment and humor in the successfulness of the viral contents too (Kulp, 2007; Hoedemaekers, 2011).

Sormunen (2009) in a study, "International viral marketing campaign planning and evaluation", discusses the role of trust in viral marketing and argues that "the growing lack of trust in marketing communications has made consumers seek information from other sources. Because consumers trust their friends, they also trust their friends' recommendations. Consumers believe that the people they know and have an ongoing relationship with will have their best interest at heart, whereas marketers are often perceived as having a mere financial interest. Trust is important factor for people in their evaluation of message credibility."

Walter et al. (2007) in a study, "A model of a trust-based recommendation system on a social network", argue that "the Trust-Aware Recommender System (TARS) is the recommender system that suggests the worthwhile information to the users on the basis of trust". This concept has been discussed by Yuan (2010) in a study, "Improved trust-aware recommender system".

Study of Godin (2001) emphasizes that an idea should be sent and gotten to be spread and a level of trust is necessary to invest the time to open the message.

\subsection{Viral Marketing and/or Trust and TAM}

Yang et al. (2012) in a study, "Predicting young Chinese consumers' mobile viral attitudes, intents and behavior" attempted to integrate TAM with two other models to predict young Chinese consumers' mobile viral attitudes, intents and behavior. The results confirmed "the chain of young Chinese consumers' viral attitudes to intents to actual behavior. Subjective norm, perceived cost and pleasure were significant predictors of their viral attitudes. 
Their viral attitudes, perceived utility and subjective norm predicted their intent to pass along entertaining electronic messages. Their intent to forward useful electronic messages was determined by their viral attitudes, perceived utility and market mavenism. Their viral attitudes, intents and market mavenism predicted their mobile viral behavior."

Yang and Zhou (2011) in a study, "Extending TPB and TAM to mobile viral marketing: An exploratory study on American young consumers' mobile viral marketing attitude, intent and behavior" show that "subjective norm, behavioral control and perceived cost are significant predictors of young American consumers' attitude toward viral marketing. Young American consumers' attitude toward viral marketing, perceived utility and telephoning predict their intent to pass along entertaining messages while perceived utility, attitude toward viral marketing, subjective norm, and monthly personal income predict their intent to forward useful messages. Young American consumers' behavior of forwarding messages is determined by attitude toward viral marketing, intent to pass along electronic messages, telephoning, texting and race."

To investigate the factors affecting adoption of users, Palka et al. (2009) applied TAM and showed the effects of trust, perceived usefulness and perceived ease of use.

Finally, there is theoretical and empirical support for integrating trust with TAM variables too (Pavlou, 2003; Gefen, Karahanna, \& Straub, 2003). Trust is one of the determinants of perceived usefulness, especially in an on-line environment, because part of the guarantee that consumers will gain their expected usefulness from the Web interface depends on the people behind the Web site (Pavlou, 2003).

\subsection{Email Viral Marketing}

As previously has been discussed, researchers usually discussed different channels for spreading messages through the VM campaigns but since the focus of this study is on email, its background research will be reviewed more.

The line between viral marketing and spam is decidedly thin. As a result, one of the most important challenges of the email-based VM campaigns is to be distinguished from the spam and email-based viruses by the consumers (Kulp, 2007; Bruyn \& Lilien, 2008; Xavier \& Summer, 2009; Lans et al., 2009). However, Xavier and Summer (2009) have showed that consumers don't view VM campaigns as spam messages while they received the messages from their acquaintances, not marketers or advertisers. Lans et al. (2009) emphasize that the design and the content of the emails require special care since customers easily categorize such emails as spam and quickly delete them.

Based on the email platform, Chiu et. al. (2008) showed that men's Internet spreading behavior is more likely to be influenced by negative message sources; women's behavior is more likely to be influenced by positive message sources. They suggest that women tend to forward a higher hedonic message than a lower hedonic message.

Proposing the multi-stage model of word-of-mouth influence through viral marketing, Bruyn and Lilien (2008) discuss three stages of engaging the target email-based campaigns. First stage is to open the received e-mail, second stage is to show some interest in the survey by following the link in the e-mail and visiting the survey's website, and finally, to complete the survey which is the final decision. Their model helps researchers to better understand the mechanisms of the influence of viral marketing.

Phelps et al. (2004) examined the attitude of the users toward the VM and what triggers them to be engaged and to pass along the emails. They showed that the entertainment value, social value (personalization of messages) and finally, awareness of the type of audience are the key motivation behind the dissemination of a message and engage in pass-along e-mailing.

\section{Methodology}

\subsection{Data Collection}

This study can be considered as an applied research from the purpose perspective and a descriptive survey with regards to the nature and method. As the research instrument, a self administered questionnaire consisting of a series of questions, designed by the researchers were used to collect required data in order to examine the hypotheses quantitatively. The questionnaire was designed to gather demographic profile of respondents (see Table 1 for the results) and the viewpoints of the participants on the considered variables. All specialized questions were on 5-point Likert scale (1="Strongly disagree" and 5="Strongly agree"). 
Table 1. Demographic profile of participants $(n=69)$

\begin{tabular}{lll}
\hline Variable & Frequency & Percent \\
\hline Gender & & \\
Male & 45 & 65.2 \\
Female & 24 & 34.8 \\
Age (Years) & & \\
$20-30$ & 37 & 53.6 \\
$31-40$ & 25 & 36.2 \\
$41-50$ & 5 & 7.2 \\
$51-60$ & 2 & 2.9 \\
Experience (Years) & & \\
$1-5$ & 35 & 50.7 \\
$6-10$ & 17 & 24.6 \\
$11-20$ & 14 & 20.3 \\
$21-30$ & 3 & 4.3 \\
Education & & \\
Technician & 6 & 8.7 \\
BS & 52 & 75.4 \\
MS & 11 & 15.9 \\
\hline
\end{tabular}

Isfahan University of Medical Sciences, Iran has been studied as the case and the target population is all of the 72 experts responsible for selection and purchase of the medical equipment in this university. Applying a census-based method, from June, 2011 to March, 2012, the questionnaire was sent to all of them and 69 filled questionnaires were returned, resulting in an effective response rate of 96 percent. Using "IBM Spss Statistics19" and "Lisrel 8.80" applications, different quantitative methods such as descriptive statistics and path analysis have been applied to analyze the gathered data.

\subsection{Hypotheses}

As it has already been argued, the purpose of this study is to evaluate the consumers' trust effect on viral marketing acceptance. Applying TAM, this goal has been followed by examining the relations of trust as an external variable and perceived usefulness, perceived ease of use, attitude toward using, intention and actual use as the original variables of the model. Considering engaging the consumers in viral marketing campaign which hereafter simply referred to as using, as the model suggests (Figure 2), perceived ease of use and trust are just independent variables and actual use is just dependent variable, the remained variables of the study including perceived usefulness, attitude toward using and intention to use play both of the roles.

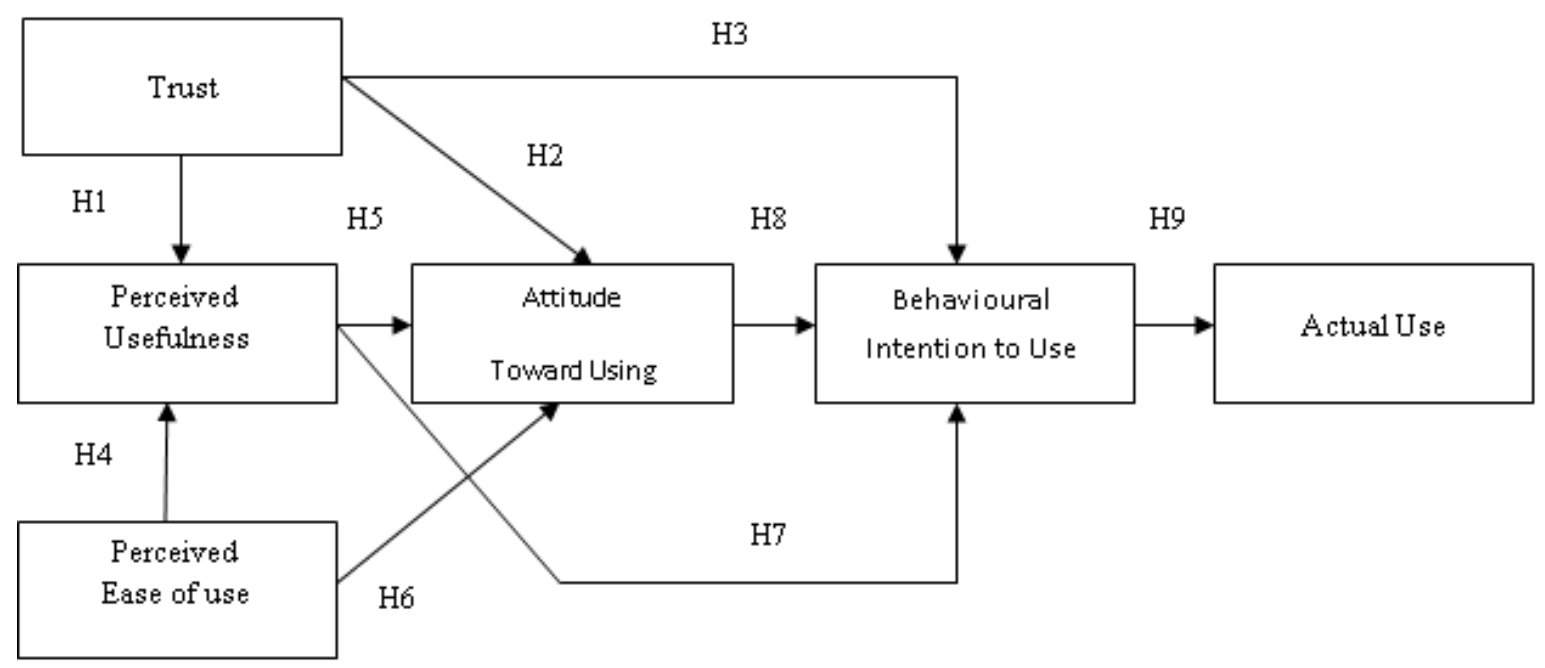

Figure 2. Authors' own model 
Based on the authors' own model, the following hypotheses were developed to be tested.

H1: Consumer's trust affects the consumer's perceived usefulness about engaging in VM.

$\mathrm{H} 2$ : Consumer's trust affects the consumer's attitude toward engaging in VM.

H3: Consumer's trust affects the consumer's intention to engage in VM.

H4: Consumer's perceived ease of use affects the consumer's perceived usefulness about engaging in VM.

H5: Consumer's perceived usefulness affects the consumer's attitude toward engaging in VM.

H6: Consumer's perceived ease of use affects the consumer's attitude toward engaging in VM.

H7: Consumer's perceived usefulness affects the consumer's intention to engage in VM.

H8: Consumer's attitude affects the consumer's intention to engage in VM.

H9: Consumer's intention affects the actual engaging in VM.

\subsection{Measures}

In this survey, trust in information of the received message and trust in the creators and forwarders of the received messages are considered as the consumers' trust. To assess respondents' trust, different dimensions have already been used by researchers however some of them are overlapped and it also depends on the context. In addition, as Mouratidis and Cofta (2010) argue, depending on the personal experiments and the culture, trust is perceived differently by individuals, so while somebody is designing the systems which require trust, the concept of the trust in the target culture should be considered.

As for this survey, four dimensions are examined: information quality which we define as "the correctness and reliability of the information.", honesty which we define as "the belief that one's partner stands by its word and is sincere." benevolence which refers to "the trustees' attempts to do good to the trustors without thinking of their own benefit" (Ingenhoff \& Sommer, 2010), and finally, commitment which we define as "an enduring desire to maintain a valued relationship ethically" (Wilson, 1995).

Regarding the abovementioned dimensions, trust was measured with the following four 5-point likely/unlikely items: "These kinds of emails, are usually correct and reliable,", "The creators and forwarders of these kinds of emails are usually honest and sincere.", "The creators and forwarders of these kinds of emails are usually benevolent and they are less thinking of their own benefit.", "The creators and forwarders of these kinds of emails are usually committed to the ethics".

As already said, the original variables of this model are perceived usefulness, perceived ease of use, attitude toward using, intention to use and actual use. Perceived ease of use was measured with the following three 5-point likely/unlikely items: Forwarding these kinds of emails to my colleagues doesn't take me so much time", "It would be easy for me to become skillful at using it", and "I would find it easy to forward these kinds of emails to my colleagues." Perceived usefulness was measured with the following four 5-point likely/unlikely items: "Forwarding these kind of emails to my colleagues would improve my performance", "Forwarding these kind of emails to my colleagues it would increase my productivity", "Forwarding these kind of emails to my colleagues would enhance my effectiveness", and "I would find it useful at work".

Attitude toward using measures users' internal beliefs and attitudes to their usage of email forwarding and was measured with the following three 5-point likely/unlikely items: "Forwarding these kinds of emails to my colleagues is a smart idea", "I like forwarding these kinds of emails to my colleagues", "Forwarding these kinds of emails to my colleagues is enjoyable for me."

Intention to use was measured with the following three 5-point likely/unlikely items: "I presently intend to actually forward these kinds of emails to my colleagues, if possible." "I will recommend the others to forward these kinds of emails", "I want to forward these kinds of emails to my colleagues more in the future".

Actual using was measured with the following three 5-point likely/unlikely items: "I have frequently forwarded the emails related to new technologies of medical products to my colleagues during the last six months.", "I have frequently forwarded the emails related to interesting medical products or brands to my colleagues during the last six months.", "I have frequently forwarded the emails related to scientific news and challenging subjects about medical equipment to my colleagues during the last six months."

Calculating Cronbach's alpha value of the scales, a reliability analysis has been done. (See Table 2) The closer Cronbach's alpha coefficient is to 1.0, the greater the internal consistency of the items in the scale. George and Mallery (2003) interpret this coefficient as excellent, if it is greater than 0.9 , good, if it's greater than 0.8 , and 
acceptable, if it's greater than 0.7. Interpreting the Cronbach's alpha coefficient for all of the items which is at least 0.815 , indicates a good internal consistency reliability. It implies that the questionnaire is reliable.

Table 2. Reliability statistics

\begin{tabular}{lll}
\hline Variable & Cronbach's Alpha & N of Items \\
\hline Actual use & 0.909 & 3 \\
Perceived usefulness & 0.867 & 4 \\
Perceived ease of use & 0.898 & 3 \\
Attitude toward using & 0.815 & 3 \\
Intention to use & 0.896 & 3 \\
Trust & 0.919 & 4 \\
\hline
\end{tabular}

\section{Data analysis and Results}

In order to test the study's hypotheses, Structural Equational Modeling (SEM) which includes two steps as measurement model and structural model has been used. Applied confirmatory factor analysis (CFA) approach indicates how observed indicators are linked to underlying latent variables. Applied path analysis was used to analyze the relationships between the predictors (independent variables) and the dependent variables.

Prior to running the factor analysis, the Kaiser-Meyer-Olkin (KMO) measure of sampling adequacy and the Bartlett's test of sphericity were conducted (Hair, Anderson, Tatham \& Black, 1998). The sampling adequacy test predicts if data are likely to factor well, based on correlation and partial correlation and a KMO measure, value greater than 0.6 (Sidiquea, Lupi \& Joshi, 2010) or even greater than 0.5 (Pankhania \& ModiFactors, 2011) is considered to be acceptable, however it supports the appropriateness of using factor analysis. (See Table 3) Bartlett's test of sphericity is used to test the null hypothesis that the variables in the population correlation matrix are uncorrelated. According to the results shown in Table 3, the significance value of Bartlett's test is 0.000 and it shows that the data meet the requirements for factor analysis and rejects the null hypothesis.

Table 3. KMO and Bartlett's test results

\begin{tabular}{lllll}
\hline Variable & KMO Measure of Sampling & \multicolumn{3}{l}{ Bartlett's Test of Sphericity } \\
\cline { 3 - 5 } & Adequacy & Chi-Square & df & Sig. \\
\hline Actual use & 0.727 & 143.540 & 3 & 0.000 \\
Perceived usefulness & 0.794 & 136.343 & 6 & 0.000 \\
Perceived ease of use & 0.760 & 137.446 & 3 & 0.000 \\
Attitude toward using & 0.649 & 82.502 & 3 & 0.000 \\
Intention to use & 0.628 & 145.976 & 3 & 0.000 \\
Trust & 0.757 & 224.511 & 6 & 0.000 \\
\hline
\end{tabular}

CFA approach specifies factor loadings as a set of regression statements from the factor to the observed variables. Using maximum likelihood as the extraction method, the factor loadings are calculated. (See table 4) All of the numbers are greater than 0.60 , thus they are interpreted as acceptable.

Table 4. Factor matrix

\begin{tabular}{lll}
\hline Variable & Question & Factor \\
\hline Actual use & 1 & 0.88 \\
& 2 & 0.92 \\
Perceived usefulness & 3 & 0.88 \\
& 4 & 0.66 \\
& 5 & 0.79 \\
Perceived ease of use & 6 & 0.82 \\
& 7 & 0.89 \\
& 8 & 0.89 \\
& 9 & 0.87 \\
\hline
\end{tabular}




\begin{tabular}{lll}
\hline Attitude toward using & 11 & 0.77 \\
& 12 & 0.96 \\
Intention to use & 13 & 0.61 \\
& 14 & 0.71 \\
Trust & 15 & 0.77 \\
& 16 & 0.75 \\
& 17 & 0.69 \\
& 18 & 0.87 \\
& 19 & 0.95 \\
\hline
\end{tabular}

In addition, goodness indexes (See Table 5) imply the acceptable goodness of the model and using the path analysis approach for the structural model, the final result for each hypothesis is extracted. The significance is denoted at the 0.05 level. Assessing the estimates and T-values, H2, H3, H4, H5, H6, H7, H8, H9 are supported but H1 is not supported.

Table 5. Goodness indexes

\begin{tabular}{llll}
\hline Chi-Square & df & P-value & RMSEA \\
\hline 249.16 & 111 & 0.008 & 0.075 \\
\hline
\end{tabular}

Table 6. Hypotheses final test

\begin{tabular}{llll}
\hline Hypothesis & Estimate & T-value & Result \\
\hline H1: Trust $\rightarrow$ Perceived usefulness & 0.15 & 1.61 & Not Supported \\
H2: Trust $\rightarrow$ Attitude & 0.58 & 2.56 & Supported \\
H3: Trust $\rightarrow$ Intention & 0.46 & 2.86 & Supported \\
H4: Perceived ease of use $\rightarrow$ Perceived usefulness & 0.42 & 3.28 & Supported \\
H5: Perceived usefulness $\rightarrow$ Attitude & 0.76 & 4.96 & Supported \\
H6: Perceived ease of use $\rightarrow$ Attitude & 0.53 & 4.61 & Supported \\
H7: Perceived usefulness $\rightarrow$ Intention & 0.51 & 3.60 & Supported \\
H8: Attitude $\rightarrow$ Intention & 1.00 & 4.58 & Supported \\
H9: Intention $\rightarrow$ Actual Use & 0.64 & 4.93 & Supported \\
\hline
\end{tabular}

\section{Discussion}

\subsection{Summary of Findings}

The previous studies which have been cited in this study showed the importance and high potential of viral marketing campaign, as a powerful, efficient and cost-effective way of marketing and brand developing. On the other hand, the purpose of this study was to evaluate the consumer's trust effect on viral marketing acceptance. Contrary to what was expected, the results showed that H1 was not supported. That is, the consumer's trust not necessarily affects the consumer's perceived usefulness in engaging in VM. This finding is not consistent with the findings from the previous studies (Ballester \& Espallardo, 2003; Pavlou, 2003), which imply that trust is one of the determinants of perceived usefulness in the on-line environment.

According to the reported results, $\mathrm{H} 2$ and $\mathrm{H} 3$ are fully supported. That is, trust affects the consumer's attitude and the consumer's intention to engaging in VM. It is consistent with the finding from the study of Ulmanen (2011) which shows that trust in online word-of-mouth has a significant impact on future intention to use a discussion forum. On the other hand, these finding confirmed earlier researches conducted by Godin (2001), Walter et al. (2007), Kurucz (2008), Palka et al. (2009), Sormunen (2009), and Pickard et al. (2010), who argued about the trust effects on the on-line behaviors, however their discussions were wider than VM and were not focused necessarily on the attitude and intention.

$\mathrm{H} 4$, which indicates perceived ease of use affects the consumer's perceived usefulness in engaging in VM, and H7, which indicates perceived usefulness affects the consumer's intention to engaging in VM, are fully supported. These findings are consistent with the finding from the previous study conducted by Pavlou (2003) who showed that perceived ease of use affects the consumer's perceived usefulness and perceived usefulness affects the 
consumer's intention in e-commerce. Also, these findings are consistent with the finding from the previous studies conducted by Yang et al. (2012) and Yang and Zhou (2011). The results of these studies confirmed that perceived utility predicts the consumers' intent to pass along entertaining electronic messages.

$\mathrm{H} 5$, which indicates perceived usefulness affects the consumer's attitude toward engaging in VM, and H6, which indicates perceived ease of use affects the consumer's attitude toward engaging in VM, are fully supported. It is consistent with prior studies such as F.D. Davis (1989) which validated TAM.

H8, which states consumer's attitude affects the consumer's intention to engaging in VM, and H9, which states consumer's intention affects the actual engaging in VM, are fully supported. These finding are consistent with the finding from the previous study conducted by Yang et al. (2012) to predict young Chinese consumers' mobile viral attitudes, intents and behavior. They showed the chain of young Chinese consumers' viral attitudes to intents to actual behavior. Their viral attitudes predicted their intent to pass along entertaining electronic messages and their intent to forward useful electronic messages was determined by their viral attitudes. In addition, their viral attitudes and intents predicted their mobile viral behavior. In the other study, the chain of American young consumers' viral attitudes to intents to actual behavior has been showed by Yang and Zhou (2011). Identifying the determinants of reception, usage, and forwarding of mobile viral content, this chain has been suggested by Palka et al. (2009) too.

Supporting H4, H5, H6, H7, H8 and H9 in this study verifies the TAM too, thus it is consistent with prior studies such as F.D. Davis (1989), Straub et al. (1997), Venkatesh and F.D. Davis (2000), Roberts and Henderson (2000), however their studies were not limited to VM. This finding implies supporting the work of Ridings et al. (2002) which showed that trust has a downstream effect on members' intentions to both give information and get information through the virtual community.

All in all, the consumer's trust effect on viral marketing acceptance was confirmed or more accurately trust in information of the received messages, trust in the creators of the received messages and trust in the forwarders of these emails, as the consumers' trust, determine the attitude and intention of the consumers and predicts whether the consumer will forward the received emails to others and will engage in the viral marketing campaign or not.

\subsection{Managerial Implications}

Today, the high potential of Internet and the growth of electronics-enhanced interactions in the virtual environment imply that the companies must increase their share of electronics-enhanced marketing and advertising approaches, especially investment on viral marketing can be suggested as a high potential solution. Although, previous studies showed that lots of famous and great multinational companies have used widely viral contents, it looks that smaller companies, especially in the studied country, Iran, need to exploit this potential more. This research showed that attitude of the consumers toward viral marketing is positive and their intention was concluded to be good, thus the companies are suggested to meet this demand and take the advantages of this level of intention by planning the suitable viral campaigns. On the other words, providing the opportunity for the consumers to be engaged in viral marketing campaigns and supporting the active consumers in different ways, depending on the context, are strongly recommended.

This study indentified trust as a challenging factor in the virtual environment in general and as an effective factor in engaging the consumers in forwarding the viral contents. Thus, the companies which are planning the viral campaigns should think of building trust actively and establish and maintain a better relationship with the consumers in order to have the positive attitude to their viral marketing campaigns and consequently more intention to be engaged. This will result in more successful viral marketing campaigns.

Since this study showed that perceived usefulness by the consumers affects their attitude toward engaging in VM and consequently affects their intention to be engaged in VM, the companies are suggested to affect the performance, advantages and usefulness of viral marketing campaigns from the consumers' perspective. This requires care in designing viral contents which should be designed in a way to be believed as really useful for them, not time consuming or not just following the profit of the company. In addition, the potential threat for a viral campaign is the negative attitude of the consumers when they think that the company is playing on their emotions. Thus, the companies should invest time and money to make some contents which are really useful for the consumers. On the other hand, this study showed that perceived ease of use affects the consumer's perceived usefulness, thus to make the campaign more useful in their opinion, companies are suggested to make it user-friendly as much as possible.

This study showed that perceived ease of use affects the consumer's attitude toward engaging in VM, so again it requires special care in designing viral contents to be accessed easily. No need to say that the consumers should 
open, read and forward the messages easily and quickly, thus the designers are suggested to use the low volume files and to focus attention on the type of the files to be opened with the usual software. Finally, they should be innovative to find the ways to increase the level of perceived usefulness, perceived ease of use, attitude and trust in their special context and for their special consumers.

\subsection{Limitations}

There are lots of researches around viral marketing but the researchers don't claim to have analyzed all or even the most important literature on the subject. No need to say that deeper study will uncover more aspects of this context.

Another shortcoming in the study is the scope. The focus of this study was merely on email as the viral marketing instrument. Although, email is so popular for VM campaigns but a wide range of instruments have been using for VM purpose and it's not limited to email VM. Remember that each form of VM offers different perspectives for researchers to be investigated.

The case study was limited to Isfahan University of Medical Sciences, Iran and the target population of 72 experts, responsible for selection and purchase of the medical equipment in this university were studied, so the results can not be generalized to others. Also, the findings of the study which are conducted in this single context can not necessarily be generalized to other contexts.

For collecting data, a single questionnaire was used but combining the quantitative results of the study with some qualitative results using in-depth interviews would help to avoid any possible bias.

TAM, which has been used in this study, is so popular but integrating viral marketing concepts with the other accepted models surely will present the other issues of VM and trust, anyway this study is limited to the variables proposed by TAM.

The study of trust as a very broad concept with the construct's complexity has been limited to the measurement of four dimensions as information quality, honesty, benevolence and commitment. In addition, trust in information of the received messages, the creators of the received messages, and the forwarders of these emails have been considered, however more issues for this concept can be defined and investigated.

\subsection{Recommendations for Future Research}

The nature of the knowledge implies that trying to find the answer of one question, new questions including new challenges will be raised and this study is not an exception.

First, the limitations described in the previous section calls for new empirical studies. Combining different contexts and different viral instruments, considering the other aspects of trust, integrating with the other verified innovation acceptance models and using different methodologies and research instruments can be some hints for the other researchers.

Second, it was concluded that to design more successful viral marketing campaigns, the companies can increase in the levels of perceived usefulness, perceived ease of use, attitude and trust from the consumer' perspective but how to increase the level of each factor, can be the subject of a new research and it calls for conducting new studies.

Third, it was described that the potential threat for a viral campaign is the negative attitude of the customers when they think that the company is playing on their emotions. It looks that it's a challenging point, especially interacting with the graduated people. Further studies can be conducted to test this hypothesis and to investigate how to face this challenge.

Fourth, the ethics of viral marketing as a relatively new concept can be attractive for the researchers. The informal nature of viral campaigns and the lack of comprehensive regulations may stress the importance of ethics in the context.

\section{References}

Ajzen, I. (1991). The theory of planned behavior. Organizational Behavior and Human Decision Processes, 50(2), 179-211. http://dx.doi.org/10.1016/0749-5978(91)90020-T

Arnott, D. C. (2007). Research on trust: a bibliography and brief bibliometric analysis of the special issue

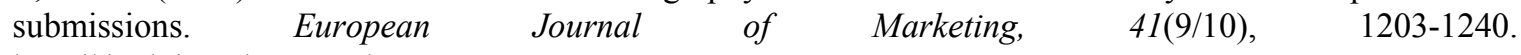
http://dx.doi.org/10.1108/03090560710773408

Bruyn, A. D., \& Lilien, G. L. (2008). A multi-stage model of word-of-mouth influence through viral marketing. International Journal of Research in Marketing, 25, 151-163. http://dx.doi.org/10.1016/j.jiresmar.2008.03.004 
Chathoth, P. K., Mak, B., Sim, J., Jauhari, V., \& Manaktola, K. (2011). Assessing dimensions of organizational trust across cultures: A comparative analysis of U.S. and Indian full service hotels. International Journal of Hospitality Management, 30(2), 233-242. http://dx.doi.org/10.1016/j.ijhm.2010.09.004

Chaffey, D., Ellis-Chadwick, F., Mayer, R., \& Johnston, K. (2006). Internet Marketing, Strategy, Implementation and Practice (3rd ed.). Pearson Education Limited.

Chen, S. C., \& Dhillon, G. S. (2003). Interpreting Dimensions of Consumer Trust in E-Commerce. International Journal of Human-Computer Studies, 4(2-3), 303-318.

Cheung, C., Lee, M., \& Rabjohn, N. (2008). The impact of electronic word-of-mouth: the adoption of online opinions in online customer communities. Internet Research, 18(3), 229-247. http://dx.doi.org/10.1108/10662240810883290

Chiu, H. C., Lee, M., \& Chen, J. R. (2008). Viral Marketing: A Study of E-Mail Spreading Behavior Across Gender. Journal of Website Promotion, 2(3), 17-30. http://dx.doi.org/10.1080/15533610802174904

Davis, F. D. (1989). Perceived usefulness, perceived ease of use, and user acceptance of information technology. MIS Quarterly, 13(3), 319-340. http://dx.doi.org/10.2307/249008

Davis, F. D., Bagozzi, R. P., \& Warshaw, P. R. (1989). User acceptance of computer technology: a comparison of two theoretical models. Management Science, 35(8), 982-1003. http://dx.doi.org/10.1287/mnsc.35.8.982

Dobele, A., Toleman, D., \& Beverland, M. (2005). Controlled infection! spreading the brand message through viral marketing. Business Horizons, 48(2), 143-149. http://dx.doi.org/10.1016/j.bushor.2004.10.011

Eckler, P., \& Rodgers, S. (2010). Viral Marketing on the Internet. Wiley International Encyclopedia of Marketing. John Wiley \& Sons Ltd. http://dx.doi.org/10.1002/9781444316568

Fetscherin, M., \& Lattemann, C. (2008). User acceptance of virtual worlds. Journal of Electronic Commerce Research, 9(3), 213-242.

Fishbein M., \& Ajzen I. (1975). Belief, attitude, intention, and behavior: an introduction to theory and research. Reading, USA: Addison-Wesley.

Gefen, D. (2000). E-commerce: the role of familiarity and trust. Omega: The International Journal of Management Science, 28(6), 725-737.

Gefen, D., Karahanna, E., \& Straub, D. W. (2003). Trust and TAM in online shopping: an integrated model. MIS Quarterly, 27(1), 51-90.

George, D., \& Mallery, P. (2003). SPSS for Windows step by step: a simple guide and reference. 11.0 update (4th ed.). Boston: Allyn \& Bacon.

Godin, S. (2001). Unleashing the ideavirus. Dobbs-Ferry, NY: Do You Zoom, Inc.

Gray, E., Seigneur, J., Chen, Y., \& Jensen, C. (2003). Trust propagation in small world. In Proceedings of 1st international conference on trust management (iTrust'03).

Hair, J. F., Anderson, R. E., Tatham. R. L., \& Black, W, C. (1998). Multivariate data analysis (5th ed.). Upper Saddle River, NJ: Prentice Hall.

Hasic, A., \& Sobtsenko, O. (2009). The Impact of viral marketing on brand awareness. Dissertation for the Degree of MA, Jönköping International Business School, Jönköping University.

Heijden, H. V. D. (2003). Factors influencing the usage of websites: the case of a generic portal in the Netherlands. Information \& Management, 40, 541-549. http://dx.doi.org/10.1016/S0378-7206(02)00079-4

Hoedemaekers, C. (2011). Viral marketing and imaginary ethics, or the joke that goes too far. Psychoanalysis, Culture \& Society, 16(2), 162-178. http://dx.doi.org/10.1057/pcs.2010.7

Hoffman, D. L., Novak, T. P., \& Peralta, M. (1999). Building consumer trust online. Communications of the ACM, 42(4), 80-85. http://dx.doi.org/10.1145/299157.299175

Hubona, G. S., \& Burton, J. A. (2003). Modeling the user acceptance of E-mail. Proceedings of the Thirty-sixth Annual Hawaii International Conference on System Sciences (HICSS).

Ingenhoff, D., \& Sommer, K. (2010). Trust in companies and in CEOs: a comparative study of the main influences. Journal of Business Ethics, 95, 339-355. http://dx.doi.org/10.1007/s10551-010-0363-y 
Kelton, K., Fleischmann, K. R., \& Wallace, W. A. (2008). Trust in digital information. Journal of the American Society for Information Science and Technology, 59(3), 363-374. http://dx.doi.org/10.1002/asi.20722

Kim, Y., \& Lowrey, T. M. (2010). Marketing communication on the Internet. Wiley International Encyclopedia of Marketing. http://dx.doi.org/10.1002/9781444316568.wiem04062

King, W. R., \& He, J. (2006). A meta-analysis of the technology acceptance mode. Information \& Management, 40(3), 191-204. http://dx.doi.org/10.1016/j.im.2006.05.003

Kiss, C., \& Bichler, M. (2008). Identification of influencers-measuring influence in customer networks. Decision Support Systems, 46(1), 233-253. http://dx.doi.org/10.1016/j.dss.2008.06.007

Koivisto, M. (2009) Mobile information system adoption and use: beliefs and attitudes in mobile context. Doctoral dissertation, Helsinki University of Technology, Faculty of electronics, communications and automation, department of communications and networking.

Kulp, S. C. (2007). Advertising among ourselves: a qualitative study of viewer attitudes towards viral marketing. Dissertation for the degree of MA, faculty of the University of North Carolina at Chapel Hill.

Kurucz, V. (2008). Perspectives of viral marketing among managers: an Internet based assessment. Dissertation for the degree of MA. University of Lugano Faculties of Communication and Economics Sciences.

Lans, R. V. D., Bruggen, G. V., Eliashberg, J., \& Wierenga, B. (2009). A viral branching model for predicting the spread of electronic word-of-mouth. Erasmus research institute of management, report ERS-2009-029-MKT, Academic Repository at Erasmus University (DEAR), DEAR ERIM Series Portal at https://ep.eur.nl/handle/1765/1.

Lee, Y., Kozar K. A., \& Larsen, K. R. T. (2003). The technology acceptance model: past, present, and future. Communications of the Association for Information Systems, 12(1), 752-780.

Litvin, S., Goldsmith, R., \& Pan, B. (2008). Electronic word-of-mouth in hospitality and tourism management. Tourism Management, 29(3), 458-468.

Mayer R. C., Davis J. H., and Davis F. D. (1995). An integrative model of organizational trust. The Academy of Management Review, 20(3), 709-734.

Mouratidis, H., \& Cofta, P. (2010). Practitioner's challenges in designing trust into online systems. Journal of Theoretical and Applied Electronic Commerce Research, 5(3), 65-77. http://dx.doi.org/10.4067/S0718-18762010000300007

Mui, L., Mohtashemi, M., \& Halberstadt, A. (2002). A Computational Model of Trust and Reputation for E-businesses. HICSS, 7, 188. http://doi.ieeecomputersociety.org/10.1109/HICSS.2002.994181

Palka, W., Pousttchi, K., \& Wiedemann, D. G. (2009). Mobile word-of-mouth - a grounded theory of mobile viral marketing. Journal of Information Technology, 24, 172-185. http://dx.doi.org/10.1057/jit.2008.37

Pankhania, T. B., \& ModiFactors, V. K. (2011). Influencing Target market criteria: a survey conducted in industries at Vitthal Udyognagar in Anand district of Gujarat state, India. International Journal of Industrial Engineering \& Production Research, 22(3), 213-220.

Pavlou, P. A. (2003). Consumer acceptance of electronic commerce: integrating trust and risk with the technology acceptance model. International Journal of Electronic Commerce, 7(3), 69-103.

Peštek, A., Resić, E., \& Nožica, M. (2011). Model of trust in e-transactions, Ekonomska istraživanja, 24(3), 131-146.

Phelps, J. E., Lewis, R., Mobilio, L., Perry, D., \& Raman, N. (2004). Viral marketing or electronic word of mouth: examining consumer responses to pass-along email. Journal of Advertising Research, 44(12), 333-348. http://dx.doi.org/10.1017/S0021849904040371

Pickard, A.J., Gannon-Leary, P., \& Coventry, L. M. (2010). Users' trust in information resources in the Web environment: a status report. JISC.

Porter, L., \& Golan, G. (2006). From subservient chickens to brawny men: A comparison of viral advertising to television advertising. Journal of Interactive Advertising, 6(2), 30-38. Online at http://jiad.org/article78

Pousttchi, K., \& Wiedemann, D. G., (2007). Success Factors in Mobile Viral Marketing: A Multi-Case Study Approach. Proceedings of the 6th International Conference on Mobile Business (ICMB 2007), 1-8. Retrieved from http://mpra.ub.uni-muenchen.de/5736/ 
Reich, S. (2010). Adolescents' sense of community on MySpace and Facebook: a mixed methods approach. Journal of Community Psychology, 38(6), 688-705. http://dx.doi.org/10.1002/jcop. 20389

Ridings, C. M., Gefe D., \& Arinze, B. (2002). Some antecedents and effects of trust in virtual communities. $\begin{array}{lllll}\text { Journal of Strategic Information } & \text { Systems, } & \text { 11(3-4), }\end{array}$ http://dx.doi.org/10.1016/S0963-8687(02)00021-5

Roberts, P., \& Henderson, R. (2000). Information technology acceptance in a sample of government employees: a test technology acceptance model. Interacting with Computers, 12(5), 427-430.

Rogers, E. (1962). Diffusion of innovations. New York, USA: The Free Press.

Rogers, E. (1995). Diffusion of innovations (4th ed.). New York, USA: The Free Press.

Salo, J., \& Karjaluoto, H. (2007). A conceptual model of trust in the online environment. Online Information Review, 31(5), 604-621. http://dx.doi.org/10.1108/14684520710832324

Sidiquea, S. F., Lupi, F., \& Joshi, S. V. (2010). The effects of behavior and attitudes on drop-off recycling $\begin{array}{llll}\text { activities. Resources, } \quad \text { Conservation and } & \text { Recycling, }\end{array}$ http://dx.doi.org/10.1016/j.resconrec.2009.07.012

Sormunen, V. (2009). International viral marketing campaign planning and evaluation. Dissertation for the Degree of MA, Department of Marketing and Management, Helsingin KAauppakorkeakoulu, Helsinki School of Economics.

Straub, D., Keil, M., \& Brenner, W. (1997). Testing the technology acceptance model across cultures: a three country study. Information and Management, 33(1), 1-11. http://dx.doi.org/10.1016/S0378-7206(97)00026-8

Testa, D. L. (2007). Mining the language of online discussions in the service of mass market communications. A dissertation presented in partial fulfillment of the requirements for the degree Doctor of Philosophy, Capella University.

Ulmanen, H. (2011). Antecedents of and their effect on trust in online word-of-mouth: case Finnish discussion forums, Dissertation for the Degree of MA, marketing university of Jyvaskyla, school of Business and Economics.

Venkatesh, V., \& Davis, F. D. (2000). A theoretical extension of the technology acceptance model: four $\begin{array}{llll}\text { longitudinal field } \quad \text { studies. Management } & \text { Science, }\end{array}$ http://dx.doi.org/10.1287/mnsc.46.2.186.11926

Venkatesh, V., Morris, M. G., Davis, G. B., \& Davis, F. D. (2003). User acceptance of information technology: toward a unified view. MIS Quarterly, 27(3), 425-478.

Walter, F., Battiston, S., \& Schweitzer, F. (2007). A model of a trust-based recommendation system on a social network. Autonomous Agents and Multi-Agent Systems, 16, 57-74.

Wang, Y., \& Vassileva, J. (2003). Trust and reputation model in peer-to-peer networks. In Proceedings of IEEE Conference on P2P Computing, 150-157.

Wang, Y., \& Vassileva, J. (2007). Toward trust and reputation based web service selection: a survey. In Multiagent and Grid Systems (MAGS) Journal, special issue on "New tendencies on Web Services and Multi-agent Systems (WS- MAS)".

Wiedemann, D. G., Palka, W., \& Pousttchi, K. (2008). Understanding the determinants of mobile viral effects-towards a grounded theory of mobile viral marketing. mobile business, ICMB '08. 7th International Conference on, 323-333.

Wilson, D. T. (1995). An integrated model of buyer-seller relationships. Journal of the Academy of Marketing Science, 23(4), 335-345. http://dx.doi.org/10.1177/009207039502300414

Woerndl, M. (2008). Internet-induced marketing techniques: critical factors in viral marketing campaigns. International Journal of Business Science and Applied Management, 3(1), 33-45.

Xavier, L. J. W., \& Summer, G. Y. S. (2009). Viral marketing communication: the Internet word-of-mouth, a study on consumer perception and consumer response. Dissertation for the Degree of MA in Business Administration, school of Management, Blekinge Institute of Technology. 
Yang, H., \& Zhou, L. (2011). Extending TPB and TAM to mobile viral marketing: an exploratory study on American young consumers' mobile viral marketing attitude, intent and behavior. Journal of Targeting, Measurement and Analysis for Marketing, 19, 85-98. http://dx.doi.org/10.1057/jt.2011.11

Yang, H., Liu, H., \& Zhou, L. (2012). Predicting young Chinese consumers' mobile viral attitudes, intents and behavior. Asia Pacific Journal of Marketing and Logistics, 24(1), 59-77. http://dx.doi.org/10.1108/13555851211192704

Yazdanifard, R., Hoe, F. K., Islam, M. R., \& Emami, S. P. (2011). Customer's information security management system in E-commerce. IPCSIT, 9, 187-191.

Yuan, W. (2010). Improved trust-aware recommender system using small-worldness of Trust Networks. Dissertation for the degree of $\mathrm{PhD}$, the faculty of the graduate school of computer engineering, Kyung Hee University, Seoul, Korea.

Zhang, L., Tan, C.P., Li, S., Fang, H., Chen, P. R. Y., Luthra, R., NG, W. K., \& Zhang, J. (2012). The influence of interaction attributes on trust in virtual communities. In Proceedings of the 19th User Modeling, Adaptation and Personalization Conference, Lecture Notes in Computer Science, 7138, 268-279. 